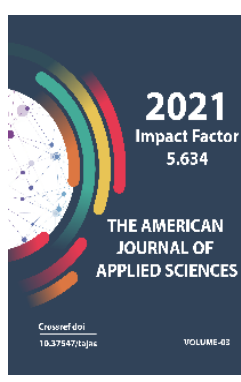

Journal Website: http://usajournalshub.c om/index,php/tajas

Copyright: Original content from this work may be used under the terms of the creative commons attributes 4.0 licence.

\section{The Role Of Free Economics In The Development Of The National Economy}

Kodirjon Maxamadaminovich Umarkulov

PhD, Associate Professor, Namangan State University, Uzbekistan

Boburmirzo Botirjon O'g'li Muhammadjonov

Master's Degree Student, Namangan State University, Uzbekistan

\title{
ABSTRACT
}

This article reveals the importance and advantages of free economic zones, studies the features, problems and shortcomings of their development in Uzbekistan, develops proposals for the development of free economic zones.

\section{KEYWORDS}

Free economic zone, small industrial zones, special economic zone, technopark, cluster.

\section{INTRODUCTION}

Strengthening macroeconomic stability in the Action Strategy for the five priority areas of development of the Republic of Uzbekistan for 2017-2021, active attraction of foreign, primarily foreign direct investment in sectors and regions of the economy, state property Many tasks have been set for the creation of favorable conditions for the development of private entrepreneurship on the basis of privatized facilities, the integrated socioeconomic development of regions, districts and cities. In fulfilling these tasks, it is 
The American Journal of Applied sciences (ISSN - 2689-0992)

Published: April 30, 2021 | Pages: 145-151

important to increase the efficiency of free economic zones (FEZ), technoparks and small industrial zones, the creation of new ones.

There is no doubt that the Decree of President Sh. Mirziyoyev dated October 26, 2016 "On additional measures to activate and expand the activities of free economic zones" will serve as a solid basis for the expansion and development of free economic zones.

Small industrial zones are areas for the placement of business entities, including engineering and communication and infrastructure facilities, a specific land area or production area, which accelerate industrial production, increase the investment attractiveness of the region for entrepreneurship, attract new investment and new technologies. It opens up a wide range of opportunities for entrepreneurship, entrepreneurship and their development. Most importantly, it provides a great advantage in the efficient use of vacant space, which is a deadly burden for society (through the development of the real economic sector), the creation of jobs for the population and the production of new competitive products..

The main part. Today, there are 23 free economic zones and 348 small industrial zones in the country, in which 453 projects worth \$ 2.6 billion have been implemented, which has created about 36,000 jobs. In small industrial zones, 1,497 projects worth 5 trillion soums have been launched and more than 36,000 people have been employed.

In the Navoi, Angren, Jizzakh, Urgut, Gijduvan, Kokand and Hazarasp free economic zones, 62 projects worth \$ 486 million have been implemented and more than 4,600 jobs have been created. 7 new free economic zones specializing in the field of pharmaceuticals, such as "Nukus-farm", "Zomin-farm", "Kosonsoy-farm", "Syrdarya-farm", "Boysunfarm", "Bostanliq-farm", "Parkent-farm" Consistent development work is underway.

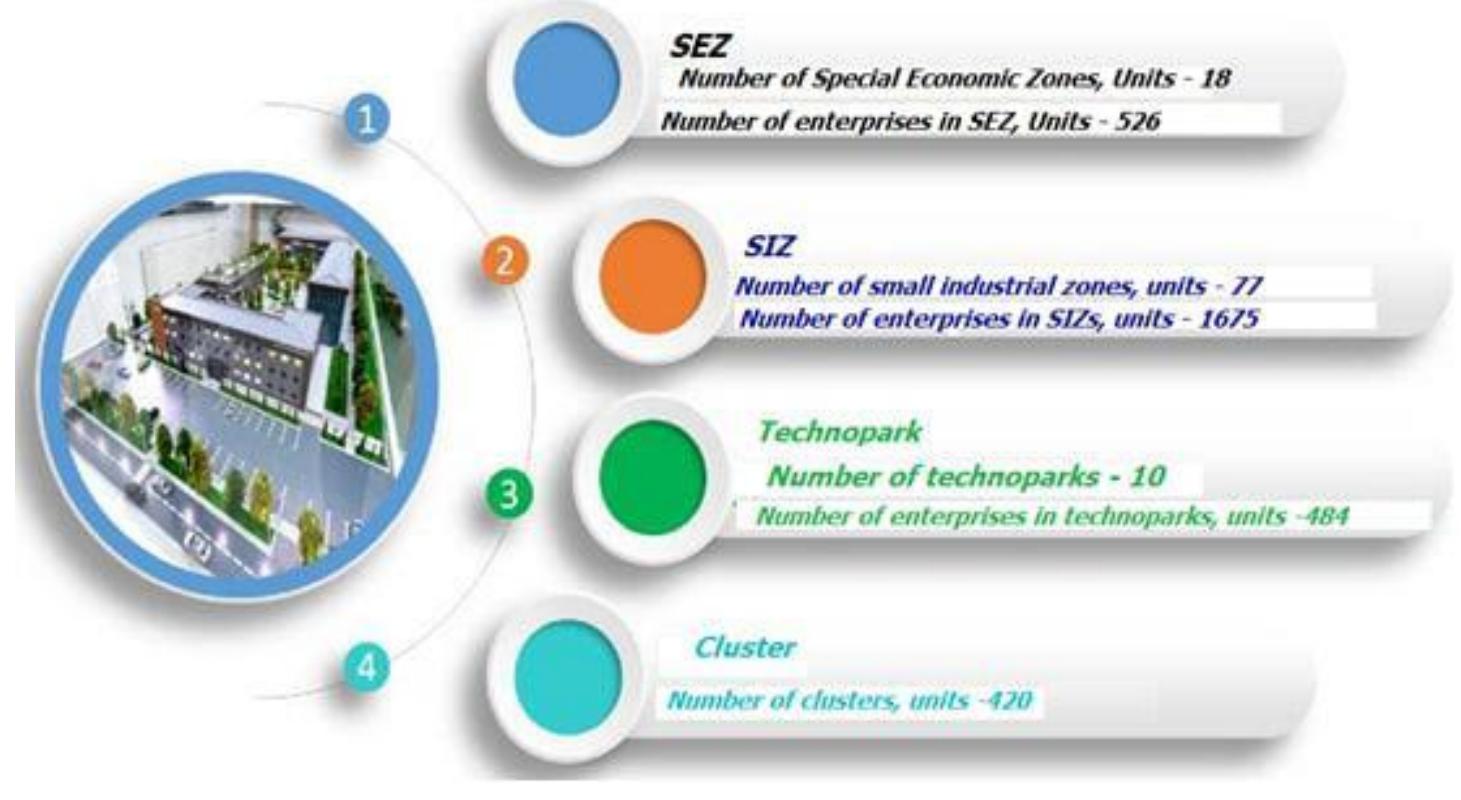

Figure 1 In 2020, the number of SIZ, KSZ, technopark and clusters 
The American Journal of Applied sciences

In order to avoid problems with access to credit and access to banking services, a specific commercial bank is attached to each zone. Based on the study of market requirements and import nomenclature, a list of proposals and promising projects for entrepreneurs has been formed. Entities operating in small industrial zones are exempt from all taxes for 2 years.
It should be noted that small production zones are areas where a special order of financial and economic activities is introduced in order to stimulate entrepreneurship, attract foreign investment in key industries, and introduce promising technologies.

table 1

Industrial production capacity of enterprises included in SIZ, KSZ, technoparks and clusters in 2020

\begin{tabular}{|c|c|c|}
\hline & Number of enterprises & $\begin{array}{c}\text { The volume of industrial production, bln. } \\
\text { in soums }\end{array}$ \\
\hline MIZ & 526 & 12268,8 \\
\hline KSZ & 1675 & 2694,2 \\
\hline Technoparks & 484 & 252,2 \\
\hline Clusters & 420 & 12609,0 \\
\hline
\end{tabular}

As can be seen from Figure 1, in 2020, a total of 18 special economic zones (SEZs), 77 small industrial zones (SIZs), 10 technoparks and 420 clusters will be established, the number of enterprises in which will be 526 in SEZs. , 1675 in KSZs, 484 in technoparks and 420 in clusters.

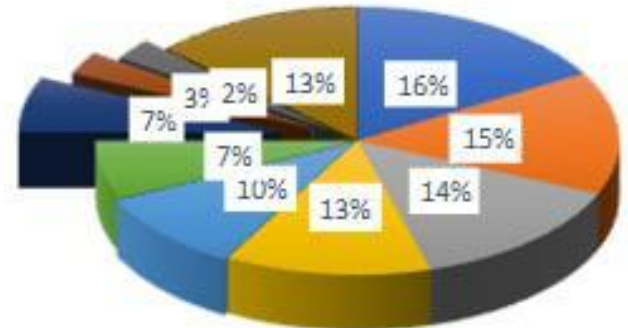

Production of rubber and plastic products

Production of finished metal products in addition to machinery and equipment

Production of computers, electronic and optical products

- Other nonmetal mineral products production

Production of motor vehicles, trailers, and semi-trailer products
- Metallurgical Industry

Production of food products

Production of textile products

Production of chemical products

- Others

Figure 2. Types of products produced by enterprises that are part of the SIZ in 2020, in\% 
As can be seen from table 1, in 2020, a total of 18 special economic zones (SEZs), 77 small industrial zones (SIZs), 10 technoparks and 420 clusters will be established, the number of enterprises in which will be 526 in SEZs, 1675 in KSZs, 484 in technoparks and 420 in clusters.

As can be seen from Figure 2, the enterprises of the SIZ provide an advantage over the production of rubber and plastic products, metallurgy, manufacture of finished metal products in addition to machinery and equipment, food production. However, the production of other types of products is relatively low.

\section{RESULTS AND DISCUSSION}

It should be noted that now Chinese goods can be seen all over the world, and by the 21st century it has truly become a "world factory". $50 \%$ of the world's cameras, $30 \%$ of air conditioners, $25 \%$ of washing machines and about $20 \%$ of refrigerators. It should be noted that free economic zones have played an important role in the development of China. At present, there are four special economic zones - Shenzhen, Zhuhai, Shantou and Xiamen. There are 14 free trade zones, 53 high and new technology zones, more than 70 scientific and technical zones for specialists trained abroad, 38 zones for processing products for export.

In general, in order to increase the competitiveness of the country's economy, the main focus should be on the use of natural resources and industrial potential of the regions and the strengthening of the export system. This is where the creation of modern free economic zones, which are an effective form of attracting foreign investment, is of particular importance. It is worth noting a number of economic measures that are widely used and effective in the world.

However, if we analyze the role of small industrial zones in attracting investment, developing entrepreneurship, creating new jobs and improving the welfare of the population, they still show a lack of initiative and a weak level of organization for business development.

For example, the process of reviewing and coordinating projects by the relevant ministries and agencies remains complex and formal. Unfortunately, there are still bureaucratic difficulties in resolving the issue of allocating land plots to the participants of the free economic zone.

In particular, in the free economic zones of Urgut, Kokand, Gijduvan and Hazarasp, as well as in the free economic zones in the field of pharmaceuticals, the work on attracting foreign investment to establish new enterprises is slow. There are also problems with the stable supply of electricity, natural gas, water and other communications. However, the period requires the development of comprehensive measures to create more opportunities for investors and entrepreneurs in these regions. First of all, it is necessary to revise the regulatory framework for the activities of these zones, if necessary, to adapt them to the requirements of the time, to create an open and understandable mechanism for all.

It is also necessary to simplify the procedure for allocating land plots and vacant buildings. For example, projects in free economic zones are considered by the Administrative Council under the Cabinet of Ministers. So far, the 
council has consisted of 17 ministries and departments. According to the presidential decree, their number is set at four. At the same time, a new system - regional commissions was established, and their powers to review and approve projects were expanded.

In addition, benefits are created by the government. The criteria for selecting investment projects for placement in economic zones will be revised, and additional measures will be taken to improve the allocation of loans to participants and provide them with engineering support. There are a number of other issues that are causing problems at work. For example, in some free economic zones, the issues related to the connection to engineering and communication networks and the construction of production infrastructure have not yet been resolved. This makes it difficult to attract investors. The directorates of free economic zones do not show enough initiative to submit proposals to commercial banks for the implementation of new investment projects.

\section{CONCLUSIONS}

Sometimes the placement of projects in free economic zones without clear calculations leads to artificial preferences for certain activities, which in turn leads to a violation of the competitive environment in the market. Therefore, strengthening the organizational and legal framework of additional opportunities, benefits and preferences provided to business entities and entrepreneurs operating in the existing free economic zones and small industries, as well as pharmaceutical zones, exporting products, creating innovative, high-tech industries. is one. In particular, in order to attract foreign investment, it is necessary to focus on the development of normative and legal documents that provide a comprehensive approach to the formation of investment projects in the regions and sectors for investors seeking to invest, aimed at fully demonstrating the country's investment potential to the world business community. At the same time, the law on free economic zones needs to be revised in accordance with today's requirements and further improved in line with the spirit of the times.

Based on the above comments, we consider it appropriate to implement the following recommendations:

- Increasing the efficiency of small industrial zones in our country;

- Organization of new ones;

- No problems with access to credit and banking services to improve the activities of small industrial zones;

- Formation of a list of proposals, promising projects for entrepreneurs based on the study of market requirements and import nomenclature;

- Full study of the potential of the regions.

\section{REFERENCES}

1. Resolution of the President of the Republic of Uzbekistan dated 25.10.2017 Resolution PQ-3356 "On additional measures to increase the efficiency of free economic zones and small industrial zones"

2. Decree of the President of the Republic of Uzbekistan PF-4947 "On the strategy of actions for further development of the Republic of Uzbekistan". February 7, 2017.

3. Resolution of the Cabinet of Ministers of the Republic of Uzbekistan dated 02.09.2017 No. 691 "Nukus-farm", "Zomin- 
farm", "Kosonsoy-farm", "Syrdarya-farm", "Boysun-farm", "Bostanliq-farm" and "Parkent-farm" in 2017-2019 Resolution "On measures to accelerate the development of transport, engineering and communication and production infrastructure in the territory of free economic zones"

4. Mamatov B.S., Xujamkulov D.Yu., Nurbekov O.Sh. Investment organization and financing. Textbook. $\mathrm{T}$ : Iqtisodmoliya, 2014.

5. Umarkulov, Kodirjon Maxamadaminovich, A Study on the Dynamics of Foreign Trade and the Issues of Regional Economic Integration in Central Asia (November 12, 2018). KIEP Research Paper. Working paper 18-05, Available at SSRN: https://ssrn.com/abstract=3299424

6. Umarkulov, Kodirjon Maxamadaminovich, "Uzbekistan and central Asia: Current situation and opportunities," ACADEMICIA: An International Multidisciplinary Research Journal, Volume: 10, Issue : 7, 27 August, 2020.

http://www.indianjournals.com/ijor.aspx? target=ijor:aca\&volume $=10$ \&issue $=7 \&$ arti cle $=071$

7. Data of the State Statistics Committee of the Republic of Uzbekistan.http://www.stat.uz

8. http://www.press-service.uz

9. Ismoilov R. B., Mullabayev B. B., Abdulxakimov Z. T (2020). Prospects For The Development Of A Tourist Route" Safed Broth Or Horn Jarir" //The American Journal of Interdisciplinary Innovations and Research. - 2020. - T. 2. - №. 08. - C. 38-44.

10. Madrahimovich, R. N., \& Bulturbayevich, M. B. (2019). Advantages of vertical integrated enterprises (under light industry enterprises). Test Engineering and Management, 81(11-12), 1596-1606.

11. Mullabayev Baxtiyarjon Bulturbayevich; Abdulxakimov Zuhrali Tursunalievich; Mamajonova Tuygunoy Ahmadjanovna; Usmanov Chorshanbi Bozorovich; Nuriddinova Nilufar Nuriddin qizi. "Development of Public-Private Partnership In The Organization of Regional Tourist And Recreational Complexes". European Journal of Molecular \& Clinical Medicine, 7, 7, 2020, 778-788.

12. Khurramov Azizbek, Abdulkhakimov Zuhrali Tursunalievich, Ibragimov Gayrat, MullabayevBaxtiyarjon Bulturbayevich, Nasrullaev Azamkhon. (2020). USE OF GRAVITY MODELS IN THE DEVELOPMENT OF RECREATION AND BALNEOLOGY. PalArch's Journal of Archaeology of Egypt / Egyptology, 17(6), 13908-13920. Retrieved from

13. Tursunalievich, A. Z., Bulturbayevich, $M$. B., Ismatullayevich, S. I., Urayimovich, B. O., \& Yokubovna, Y. H. (2021). Use of Gravitation Models in the Development of Tourism and Recreation. Annals of the Romanian Society for Cell Biology, 31243143.

14. Makhmudov Bakhriddinkhon Jo'rayevich; Ismoilov Ravshanjon Baxritdinovich; Mullabayev Baxtiyarjon Bulturbayevich. "The Role Of Regional Governance In The Development Of Small Business And Private Entrepreneurship". European Journal of Molecular \& Clinical Medicine, 7 , 7, 2020, 705-711.

15. Солиев И.И, Сирожиддинов К.И.Благоприятный инвестиционный климат - важный фактор макроэкономического развития. 
The American Journal of Applied sciences (ISSN - 2689-0992)

Published: April 30, 2021 | Pages: 145-151

Doi: https://doi.org/10.37547/tajas/Volume03Issue04-20

Молодой ученый. 461-463 с. https://www.elibrary.ru/item.asp?id=2413 2188

16. Солиев и.и, Сирожиддинов К.И.Вопросы поддержания конкурентоспособности аграрных производелей. Молодой ученый. 317-322 c.

https://www.elibrary.ru/item.asp?id=4400 2041

17. Умаркулов K,M (2020). Узбекистан и Центральная Азия: текущая ситуация и возможности. ACADEMIYA. том 10, выпуск 7. 10.5958 / 22497137.2020.00891.5

18. Umarkulov, Kodirjon Maxamadaminovich, 2018. "A Study on the Dynamics of Foreign Trade and the Issues of Regional Economic Integration in Central Asia," Working Papers 18-5, Korea Institute for International Economic Policy. https://ideas.repec.org/p/ris/kiepwp/2018 _005.html

19. Jurabaevich, S. N., \& Bulturbayevich, M. B. (2021). IMPROVING ECONOMIC DIAGNOSTICS AND ITS IMPLEMENTATION MECHANISM IN ASSESSING THE QUALITY OF HIGHER EDUCATION. Emergent: Journal of Educational Discoveries and Lifelong Learning (EJEDL), 1(01), 1-10.

20. OlimSabirovichKazakov,\&llhomMahamad janovichKamoliddinov. (2021). SOME QUESTIONS OF INCREASE OF EFFICIENCY IN ACTIVITY ENTERPRISE SUBJECTS. Journal of Central Asian Social Studies, 2(01), 160-169. https://doi.org/10.37547/jcass/volumeo2iss ue01-a24

21. KazakovO. (2020). КИЧИК БИЗНЕС СУБЪЕКТИДА ИШЛАБ ЧИҚАРИШ ФАОЛИЯТИНИ РИВОЖЛАНТИРИШ ЙЎЛЛАРИ. АрхИв научных исследований, 1(2).извлечено от https://tsue.scienceweb.uz/index.php/arc hive/article/view/3729

22. «Менежмент организации». Под ред. 3.П.Румянцевой. Учебное пособие. Москва «Инфра-М» 1996

23. Мескон М., Альберт М., Хедоури Ф. «Основы менежмента» М., Дело.1992 г.

24. Казаков О.С. Менежментга кириш. Дарслик. Тошкент. “Фан зиёси” нашриёти, 2021 й.

25. Kazakov, O. S., \& Ahmedkhodjaev, X. T. (2017). Fundamentals of management. Tashkent, Ilm-Ziyo.

26. Kazakov O. (2020). IMPROVING THE MANAGEMENT ACTIVITY OF THE FRUIT AND VEGETABLE INDUSTRY ENTERPRISES. Архив научных исследований, 1(2). извлечено от https://tsue.scienceweb.uz/index.php/arc hive/article/view/3731

27. Qozoqov, O. docent and Qozoqov, S. (2020) "WAYS TO INCREASE THE EFFICIENCY OF USING EQUIPMENT AND TECHNOLOGY IN THE CONDITIONS OF DIGITAL ECONOMY," International Finance and Accounting: Vol. 2020 : Iss. 5 , Article 30.

Available at: https://uzjournals.edu.uz/interfinance/vol 2020/iss5/30

28. Olim Sabirovich Kazakov, \& Ilhom Mahamadjanovich Kamoliddinov. (2021). SOME QUESTIONS OF INCREASE OF EFFICIENCY IN ACTIVITY ENTERPRISE SUBJECTS. Journal of Central Asian Social Studies, 2(01), 160-169. https://doi.org/10.37547/jcass/volume02iss ue01-a24 